\title{
The comparasion of music teacher candidates' instrument test grades and instrument sight reading grades in talent exam with individual instrument exam grades during four- years education period ${ }^{1}$
}

\author{
Meltem Düzbastılar ${ }^{2}$
}

\begin{abstract}
Every year Music education programs of the education Faculties, select students through out a talent test. This study aims to compare the instrument test grades and instrument sight reading grades at the talent test with individual instrument test grades of the students of Education Faculty Fine Arts Education Branch Music Education department. At the same time, the study aims to compare the instrument test grades and instrument sight reading grades at the talent test with individual instrument test grades of the students at first, second, third and fourth calass according to the high schools that students graduated. This research is important bescause of showing the 4 year progress of the students from the point of individual instrument playing; at the same time it is important for showing the progress of Fine Arts High School graduates and other high school graduates, and the difference between two groups. In this research relational search method will be used. The sample of the study consists of 176 student who became successfull at the talent exams in 2012, 2013, 2014 ve 2015 and registered to the Education Faculty Fine Arts Education Branch Music Education department of a University located in Black Sea Reagion. The data of the research is obtained by the approval of the deanship of the Faculty. The data will be analysed with a statistical analyse program which is used for the social sciences. As the result of the study the progress and the difference of the instrument playing and instrument sight reading scores will be shown as tables and will be commented.
\end{abstract}

Keywords: Talent Exam, Instrument Sight Reading, Individual Instrument.

\section{Introduction}

In Turkey, there are lost of criterions that can be used as base for identifying the abilities and knowledge which required for the students who want to attend to higer education. The criterion for the students who want to take music education is the talent test (Günesstan, 2018, s.36). talent test mesure the different dimension of musical talent. It means to mesure the secret power of the student from the point of musical success by focusing on the talent like tonal memory, rythm memory, differentiating the intervals, chord analysing and musical sensitivy (Aktaran: Yağc1, 2009:

\footnotetext{
1 This article is presented in the "6th International Conference on Social Sciences and Education Research" in Kiev, Ukraine (05-07 September 2019).

2 Assoc. Prof. Dr. Trabzon University, Fatih Education Faculty, Branch of Fine Arts, Music Education Department, meltemerol78@yahoo.com (iD) 0000-0001-8346-596X.
} 
Düzbastilar, M. (2020). The comparasion of music teacher candidates' instrument test grades and instrument sight reading grades in talent exam with individual instrument exam grades during four-years education period. Journal of Human Sciences, 17(1), 315-323. doi:10.14687/jhs.v17i1.5867

16; Richardson, 1990: 2). In our country, music education faculties hold special talent examinations for discover the abilities of candidates during while choosing students.

The talent exams were held as two phaces between 2012-2015 at the music education branch of the university which the research is done. At first phace, there is dictation, two voices hearing, three voices hearing, four voices hearing, melody and rhythm repetition and at the second phace musical playing, musical singing and solfages (Guide, 2012-2015).

At the second phace, canditates were expected to answer musical playing, musical singing and solfages questions correctly. The candidates are expected to sing and play the compositions that they prepare and to give the correct answers to the questions about the notes, sound intervals, sound frequencies and rythyms. Solfege questions are evaluated through the correct and clear reading of the notes based on notes and rythym knowledge (Exam guide, 2012-2015). Solfege, musical singing and playing exams are evaluated over 100 point.

This study aims to compare the Education Faculty Fine Arts Education Branch Music Education department students' instrument test grades and instrument sight reading grades at the talent test with individual instrument test grades at the first class, second class, third class and fourth class. At the same time, the study aims to compare the students' instrument test grades and instrument sight reading grades at the talent test with individual instrument test grades at first, second, third and fourth calass according to the variable of high schools that students graduated.

While searching the related publications, it's seen that there are several researches about Instrument education, sight playing. In Kurtuldu's study published in 2014 named "The Compare of The Succes in Piano Lessons And Sight Playing Abilities of The Students" the relationship between the piano students' success in piano lessons and their ability in sight playing is examined. As the result of the statistical analyses, it's understood that there is a direct proportion and close relationship.

In Canbey and colleagues study published in 2012 named "Music Education Students' Opinions About the Importanca of Sight Reading in Piano Education" the thoughts of the music students about the importance of sight reading in piano education took place. As the conclusion of the study it is understood that sight reading exercises in piano lessons are not enough and students do not see themselves successfull in this subject.

In 2016, Can completed his study named "The Effect of Daily Working Programs on The Student's Behaviours About Instrument Working, Guitar Sight Playing And Performance in Classical Guitar Education" As the result, there is a meaningful differance between the experiment group (students fallowing a daily working program) and control groups in favour of experiment groups according to the total points obtained from the guitar performance degree scale and sight playing scale.

\subsection{The Aim of the Study}

This study is prepared aiming to compare the Education Faculty Fine Arts Education Branch Music Education department students' instrument test grades and instrument sight reading grades at the talent test with individual instrument test grades at the first class, second class, third class and fourth class. At the same time, the study aims to compare the students' instrument test grades and instrument sight reading grades at the talent test with individual instrument test grades at first, second, third and fourth calass according to the variable of high schools that students graduated.

In this context, the sub-problems of the study is listed below:

1. Sub-Problem: What is the relationship between the instrument test grades and instrument sight reading grades at the talent test with individual instrument test grades at the first class?

2. Sub-Problem: What is the relationship between the instrument test grades and instrument sight reading grades at the talent test with individual instrument test grades at the second class? 
Düzbastilar, M. (2020). The comparasion of music teacher candidates' instrument test grades and instrument sight reading grades in talent exam with individual instrument exam grades during four-years education period. Journal of Human Sciences, 17(1), 315-323. doi:10.14687/jhs.v17i1.5867

3. Sub-Problem: What is the relationship between the instrument test grades and instrument sight reading grades at the talent test with individual instrument test grades at the third class?

4. Sub-Problem: What is the relationship between the instrument test grades and instrument sight reading grades at the talent test with individual instrument test grades at the fourth class?

5. Sub-Problem: How is the four year individual instrument progress of the students graduated from Fine Arts High Schools and others who became successfull in talent exam and registered to the faculty?

\subsection{The Importance of the Study}

This research is important bescause of showing the 4 year progress of the students from the point of individual instrument playing; at the same time it is important for showing the progress of Fine Arts High School graduates and other high school graduates, and the difference between two groups.

\subsection{Hypothesis}

This study is based on the following assumptions:

1. It is assumed that the scores which is the base of the research are determined by valid and reliable methods.

2. It is assumed that the searching method and analysing thecnics are proper.

\subsection{Boundries}

1. The study is limited with the analyses of the the instrument test grades and instrument sight reading grades at the talent test with individual instrument test grades of the same students of the related university Education Faculty Fine Arts Education Branch Music Education department for four years.

2. The study is limited with 176 students who became successfull in talent tests and registered to school in 2012, 2013, 2014 and 2015.

\section{Method}

In this part, there is information about research model, study group, collecting data and data analysing methods.

\subsection{Research Model}

In this research, corelational research model which is a kind of relational research is used. Corelational researches aim to describe the relationship between two or more variables without intervening them (Karakaya, 2014, s.68; Büyüköztürk, Kılıç Çakmak, Karadeniz ve Demirel, 2016, s.185).

\subsection{Study Group}

The study group of this article consists of 176 students who became successfull talent exam of the related university's Education Faculty Fine Arts Branch Music Education Department in 2012, 2013, 2014, 2015 and registered to Faculty. 
Düzbastilar, M. (2020). The comparasion of music teacher candidates' instrument test grades and instrument sight reading grades in talent exam with individual instrument exam grades during four-years education period. Journal of Human Sciences, 17(1), 315-323. doi:10.14687/jhs.v17i1.5867

Table 1. Working group data table

\begin{tabular}{cccccc}
\hline Education Period & \multicolumn{2}{c}{ Other High } & \multicolumn{2}{c}{ Fine Arts High } & TOTAL \\
& \multicolumn{2}{c}{$\begin{array}{c}\text { School Graduates } \\
\text { School Graduates }\end{array}$} & \\
& $\mathbf{N}$ & $\%$ & $\mathbf{N}$ & $\%$ & $\mathbf{N}$ \\
\hline $\mathbf{2 0 1 2 - 2 0 1 3}$ & 6 & $14 \%$ & 37 & $86 \%$ & 43 \\
$\mathbf{2 0 1 3 - 2 0 1 4}$ & 6 & $14 \%$ & 37 & $86 \%$ & 43 \\
$\mathbf{2 0 1 4 - 2 0 1 5}$ & 10 & $21,7 \%$ & 36 & $78,3 \%$ & 46 \\
$\mathbf{2 0 1 5 - 2 0 1 6}$ & 8 & $18,2 \%$ & 36 & $81,8 \%$ & 44 \\
\hline
\end{tabular}

30 of the $176(17 \%)$ students are the garaduates of other schools. $146(83 \%)$ students graduated from Fine Arts High Schools.

\subsection{Collecting Data}

The data of the research is obtained from related university's Education Faculty Fine Arts Branch Music Education Department with the approval of the dean on the condition that the name of the university is not stated. So the name of the university and the faculty is not stated in the study.

\subsection{Analysing the Data}

The data is analysed by using a statistical program which is frequently used in social sciences. Before the corelational measurments, normality of the data is checked and kurtosis and skewness coefficients of the data are controlled. The results of kurtosis and skewness analysis of the data is given in Table-2.

Table 2. Kurtosis and skewnwss coefficients of the analysed parameters

\begin{tabular}{|c|c|c|c|c|}
\hline \multirow[t]{2}{*}{ EXAM GRADES } & \multicolumn{2}{|c|}{ Skewness } & \multicolumn{2}{|c|}{ Kurtosis } \\
\hline & Statistic & Std. Error & Statistic & Std. Error \\
\hline $\begin{array}{l}2012 \text { Talent Exam Instrument } \\
\text { Grades }\end{array}$ &,- 778 & ,337 &,- 072 & ,662 \\
\hline $\begin{array}{c}2012 \text { Talent Exam Sight Playing } \\
\text { Grades }\end{array}$ & $-1,395$ & ,337 & 1,674 & 662 \\
\hline $\begin{array}{l}\text { First Class Individual Instrument } \\
\text { Final Exam Grade }\end{array}$ &,- 139 & 357 &,- 746 & 702 \\
\hline $\begin{array}{l}2013 \text { Talent Exam Instrument } \\
\text { Grades }\end{array}$ & ,056 & ,337 & $-1,074$ & ,662 \\
\hline $\begin{array}{l}2013 \text { Talent Exam Sight Playing } \\
\text { Grades }\end{array}$ &,- 728 & ,337 &,- 468 & 662 \\
\hline $\begin{array}{c}\text { Second Class Individual } \\
\text { Instrument Final Exam Grade }\end{array}$ &,- 235 & 378 & $-1,289$ & 741 \\
\hline $\begin{array}{c}2014 \text { Talent Exam Instrument } \\
\text { Grades }\end{array}$ &,- 523 & ,337 &,- 188 & 662 \\
\hline $\begin{array}{c}2014 \text { Talent Exam Sight Playing } \\
\text { Grades }\end{array}$ & $-1,042$ & ,337 & 762 & 662 \\
\hline $\begin{array}{l}\text { Third Class Individual Instrument } \\
\text { Final Exam Grade }\end{array}$ &,- 298 & ,337 &,- 467 & 662 \\
\hline $\begin{array}{c}2015 \text { Talent Exam Instrument } \\
\text { Grades }\end{array}$ &,- 573 & ,337 &,- 599 & 662 \\
\hline $\begin{array}{l}2015 \text { Talent Exam Sight Playing } \\
\text { Grades }\end{array}$ & $-1,307$ & 337 & 1,605 & 662 \\
\hline $\begin{array}{c}\text { Fourth Class Individual } \\
\text { Instrument Final Exam Grade }\end{array}$ &,- 278 & ,350 &,- 276 & 688 \\
\hline
\end{tabular}


Düzbastilar, M. (2020). The comparasion of music teacher candidates' instrument test grades and instrument sight reading grades in talent exam with individual instrument exam grades during four-years education period. Journal of Human Sciences, 17(1), 315-323. doi:10.14687/jhs.v17i1.5867

If the kurtosis and skewness coefficient is 0 , it shows that distribution is standart normal distribution; if it is different from 0, it shows standart normal distribution changes (Köklü and Büyüköztürk, 2000, p.68.; Baykul, 1999, p.134; Altunış1k vd. 2005, p.156). In analyses, it’s important that the variance of the scores shouldn't be high. If the variance is between $+1-1$, it indicates that the scores doesn't show an important variance from the normal distribution (Köklü vd. 2006, s.63; Keskin and Çiçek, 2005, s.54). In theoretical normal distribution, distribution is continious and begins from (-) infinite, ends $(+)$ infinite. $99.74 \%$ of the subjects are between the borders of $+3-3$ (Alpan and Arpacik, 1990, p.58; Ar1c1, 2005, p.198) Albayrak vd. (2005, p.209), noted that the kurtosis may be between the borders of +3 ile -3 .

\section{Findings and Comments}

In this part the findings of the study are presented in the same order with the sub-problems.

\subsection{The Findings and Comments About the First Sub-Problem}

The first Sub-Problem of the study is "What is the relationship between the instrument test grades and instrument sight reading grades at the talent test with individual instrument test grades at the first class?" The relationship between Talent Exam and Individual Instrument Final Exam grades are shown in Table-3.

Table 3. The relationship between talent exam and Individual Instrument final exam grades

\begin{tabular}{ccc}
\hline FIRST CLASS & $\begin{array}{c}\text { Talent Exam } \\
\text { (Instrument) }\end{array}$ & $\begin{array}{c}\text { Talent Exam } \\
\text { Playig) }\end{array}$ \\
\hline Individual Instrument Final Exam &,- 114 &,- 160 \\
\hline
\end{tabular}

The Correlation Coefficient between Talent Exam Instrument Grades and First Class Individual Instrument Final Exam of 176 students who registered to school between 2012-2015 is 114. The Correlation Coefficient between Talent Exam Sight Playing grades and First Class Individual Instrument Final Exam is -,160. These values means that there is a negative and weak relationship between Talent Exam Instrument- Sight Playing Grades and First Class Individual Instrument Final Exam.

\subsection{The Findings and Comments About the Second Sub-Problem}

The second sub-problem of the study is "What is the relationship between the instrument test grades and instrument sight reading grades at the talent test with individual instrument test grades at the second class?" The relationship between Talent Exam and Individual Instrument Final Exam grades are shown in Table-4.

Table 4. The relationship between the instrument test grades and instrument sight reading grades at the talent test with individual instrument test grades at the second class

\begin{tabular}{cccc}
\hline SECOND CLASS & $\begin{array}{c}\text { Talent Exam } \\
\text { (Instrument) }\end{array}$ & $\begin{array}{c}\text { Talent Exam } \\
\text { Playig) }\end{array}$ & (Sight \\
\hline Individual Instrument Final Exam &, 084 &,- 056 \\
\hline
\end{tabular}

The Correlation Coefficient between Talent Exam Instrument Grades and Second Class Individual Instrument Final Exam of the students is ,084 The Correlation Coefficient between Talent Exam Sight Playing grades and First Class Individual Instrument Final Exam is -,056. These values show that there is a weak relationship or almost no relationship between Talent Exam Instrument- Sight Playing Grades and Second Class Individual Instrument Final Exam. 
Düzbastilar, M. (2020). The comparasion of music teacher candidates' instrument test grades and instrument sight reading grades in talent exam with individual instrument exam grades during four-years education period. Journal of Human Sciences, 17(1), 315-323. doi:10.14687/jhs.v17i1.5867

\subsection{The Findings and Comments About the Third Sub-Problem}

The third sub-problem of the study is "What is the relationship between the instrument test grades and instrument sight reading grades at the talent test with individual instrument test grades at the third class?" The relationship between talent exam grades and Individual Instrument Final exam is given in table 5 .

Table 5. The relationship between the instrument test grades and instrument sight reading grades at the talent test with individual instrument test grades at the third class

\begin{tabular}{ccc}
\hline THIRD CLASS & $\begin{array}{l}\text { Talent Exam } \\
\text { (Instrument) }\end{array}$ & $\begin{array}{c}\text { Talent Exam } \\
\text { (Sight Playig) }\end{array}$ \\
\hline Individual Instrument Final Exam &,- 227 &, 170 \\
\hline
\end{tabular}

The Correlation Coefficient between Talent Exam Instrument Grades and Third Class Individual Instrument Final Exam of the students is -,227. The Correlation Coefficient between Talent Exam Sight Playing grades and First Class Individual Instrument Final Exam is ,17.

While there is a negative and weak relationship between Talent Exam Instrument Grades and Third Class Individual Instrument Final Exam, the relationship between Sight Playing Grades and Third Class Individual Instrument Final Exam is very weak.

\subsection{The Findings and Comments About the Fourth Sub-Problem}

The third sub-problem of the study is "What is the relationship between the instrument test grades and instrument sight reading grades at the talent test with individual instrument test grades at the fourth class?" The relationship between talent exam grades and Individual Instrument Final exam is given in table 6 .

Table 6. The relationship between the instrument test grades and instrument sight reading grades at the talent test with individual instrument test grades at the fourth class

\begin{tabular}{cccc}
\hline FOURTH CLASS & Talent Exam (Instrument) & $\begin{array}{c}\text { Talent Exam } \\
\text { Playig) }\end{array}$ & (Sight \\
\hline $\begin{array}{c}\text { Individual Instrument Final } \\
\text { Exam }\end{array}$ &,- 010 &,- 053 \\
\hline
\end{tabular}

The Correlation Coefficient between Talent Exam Instrument Grades and Fourth Class Individual Instrument Final Exam of the students is -,010. The Correlation Coefficient between Talent Exam Sight Playing grades and First Class Individual Instrument Final Exam is -,053.

According to these values there is a weak relationship or almost no relationship between Talent Exam Instrument- Sight Playing Grades and Fourth Class Individual Instrument Final Exam.

\subsection{The Findings and Comments About the Fifth Sub-Problem}

The fifth sub problem of the study is "How is the four year individual instrument progress of the students graduated from Fine Arts High Schools and others who became successfull in talent exam and registered to the faculty?" The values in Table 7 shows the difference between the talent test scores and individual instrument scores over 100. (-) values means the grades decreased in individual instrument exam; and $(+)$ values means that the scores increased. 
Düzbastilar, M. (2020). The comparasion of music teacher candidates' instrument test grades and instrument sight reading grades in talent exam with individual instrument exam grades during four-years education period. Journal of Human Sciences, 17(1), 315-323. doi:10.14687/jhs.v17i1.5867

Table 7. The talent exam instrument grades and the individual instrument exam grades of fine arts high school graduates and other school graduates

\begin{tabular}{|c|c|c|c|}
\hline & $\begin{array}{c}\text { The } \\
\text { Average of } \\
\text { Talent } \\
\text { Exam } \\
\text { Instrument } \\
\text { Grades }\end{array}$ & $\begin{array}{l}\text { The Average of } \\
\text { Final Instrument } \\
\text { Exam Grades }\end{array}$ & $\%$ Difference \\
\hline \multirow{4}{*}{ Other High School Graduates } & \multirow{4}{*}{78} & 85 (1st class) & $\% 7$ \\
\hline & & 77 (2nd class) & $(-) \% 1$ \\
\hline & & 82 (3rd class) & $\% 4$ \\
\hline & & 83 (4th class) & $\% 5$ \\
\hline \multirow{4}{*}{$\begin{array}{c}\text { Fine Arts High School } \\
\text { Graduates }\end{array}$} & \multirow{4}{*}{80} & 77 (1 st class) & $(-) \% 3$ \\
\hline & & 72 (2nd class) & $(-) \% 8$ \\
\hline & & 76 (3rd class) & $(-) \% 4$ \\
\hline & & 83 (4th class) & $\% 3$ \\
\hline
\end{tabular}

Table 8. The talent exam sight playing grades and the individual instrument exam grades of fine arts high school graduates and other school graduates

\begin{tabular}{|c|c|c|c|}
\hline & $\begin{array}{c}\text { The Average of } \\
\text { Talent Exam } \\
\text { Sight Playing } \\
\text { Grades }\end{array}$ & $\begin{array}{l}\text { The Average of } \\
\text { Final Instrument } \\
\text { Exam Grades }\end{array}$ & $\%$ Difference \\
\hline \multirow{4}{*}{$\begin{array}{l}\text { Other High School } \\
\text { Graduates }\end{array}$} & \multirow{4}{*}{57} & 85 (1 st class) & $\% 28$ \\
\hline & & 77 (2nd class) & $\% 20$ \\
\hline & & 82 (3rd class) & $\% 25$ \\
\hline & & 83 (4th class) & $\% 26$ \\
\hline \multirow{4}{*}{$\begin{array}{c}\text { Fine Arts High School } \\
\text { Graduates }\end{array}$} & \multirow{4}{*}{79} & 77 (1 st class) & $(-) \% 2$ \\
\hline & & 72 (2nd class) & $(-) \% 7$ \\
\hline & & 76 (3rd class) & $(-) \% 3$ \\
\hline & & 83 (4th class) & $\% 4$ \\
\hline
\end{tabular}

The average talent exam grades of the students graduated from other schools between 20122015 is 78, and the average of talent exam sight playing grades is 57 . These students increased their average grades to 85 at the end of the first year. At the end of the second year the average grade decreased but in third and fourth classes increased again.

The average talent exam grades of the students graduated from Fine Arts Highschools is 80 and average of talent exam sight playing grade is 79 . At the end of the first class the average individual instrument grade decreased to 77 . At the second class it cotiniued to decrease and the average grade became 72 . At the third class it increased and became 76 and at fourth class final exams it increased to 83 .

The changes of the average grades are shown on the last columns of the tables. 
Düzbastilar, M. (2020). The comparasion of music teacher candidates' instrument test grades and instrument sight reading grades in talent exam with individual instrument exam grades during four-years education period. Journal of Human Sciences, 17(1), 315-323. doi:10.14687/jhs.v17i1.5867

\section{Conclusions and Discussion}

As the result of the study, it is understood that;

There is a negative and weak relationship between Talent Exam Instrument- Sight Playing Grades and First Class Individual Instrument Final Exam.

There is a weak relationship or almost no relationship between Talent Exam InstrumentSight Playing Grades and Second Class Individual Instrument Final Exam.

While there is a negative and weak relationship between Talent Exam Instrument Grades and Third Class Individual Instrument Final Exam, the relationship between Sight Playing Grades and Third Class Individual Instrument Final Exam is very weak.

There is a weak relationship or almost no relationship between Talent Exam InstrumentSight Playing Grades and Fourth Class Individual Instrument Final Exam.

The average talent exam grades of the students graduated from other schools between 2012-2015 is 78, and the average of talent exam sight playing grades is 57 . These students increased their average grades to 85 at the end of the first year. At the end of the second year the average grade decreased but in third and fourth classes increased again.

The average talent exam grades of the students graduated from Fine Arts Highschools is 80 and average of talent exam sight playing grade is 79 . At the end of the first class the average individual instrument grade decreased to 77 . At the second class it cotiniued to decrease and the average grade became 72 . At the third class it increased and became 76 and at fourth class final exams it increased to 83.

\section{Recommendations}

The importance benefits of the sight playing may be explained or reminded to the students.

In individual instrument lessons more sight playing exercises should be done and sight playing homeworks may be given.

Especially the graduates of Fine Arts Highschools may be guided for improving their instrument playing and sight playing abilities.

\section{References:}

Albayrak, A. S., vd. (2005). SPSS Uygulamal çok değģskenli İstatistik teknikleri, Ankara: Asil yayin Dağıllim Ltd. Şti.

Alpan, O., Arpac1k, R. 1990. İstatistik Uygulamalar, Ankara: Veteriner fakültesi.

Altunısı1k, R., vd. (2005). Sosyal Bilimlerde Araștırma Yöntemleri, İstanbul: İstanbul.Baskı: Avc1 Ofset.

Arıc1, H. 2005. Istatistik Yöntem ve Uygulamalar, Meteksan AŞ. Ankara.

Aypay, A., vd. (2014). Bilimsel Araștırma Yöntemleri, Ankara: Anı Yayıncilık.

Baykul, Y. 1999. İstatistik Metodlar ve Uygulamalar, Ankara: Anı Yayınc1lik.

Büyüköztürk, Ş., vd. (2016). Bilimsel Arastırma Yöntemleri, Ankara: Pegem Akademi.

Can, Ü., K. (2016). Klasik Gitar Eğitiminde Günlük Çalışma Programının Gitar Öğrencilerinin Çalg1 Çalışmaya İlişkin Tutumlarına, Gitar Deşifrelerine ve Performanslarına Etkisi, Eğitim ve Bilim, Cilt 41 (2016) Say1 185 235-250.

Canbey, E., G. vd. (2012). Müzik Eğitimi Anabilim Dalında Öğrenim Gören Öğrencilerin Piyano Eğitiminde Deşifrenin Önemine Yönelik Düşünceleri. Eğitim ve Öğretim Araștırmalar Dergisi, Journal of Research in Education and Teaching, Mayıs, Haziran, Temmuz 2012 Cilt:1 Say1:2 ISNN: 2146-9199.

Erdoğan. G. (2013). Bireysel Calgrssyla Canl Mürike Yapan Ve Yapmayan Müzik Bölümü Öğrencilerinin Calgzlarnndaki Başar Durumlar, Yüksek Lisans Tezi, T.C. Cumhuriyet Üniversitesi Eğitim Bilimleri Enstitüsü Güzel Sanatlar Eğitimi Ana Bilim Dalı Müzik Eğitimi Bilim Dalı, Sivas.

Exam guide. (2012-2017). Ë̆itim Fakültesi Müzik Öğretmenlï̆i ve Resim-Ișs Ögretmenliği, Güzel Sanatlar Fakültesi Resim Bölümü 2012 Yıl Özеl Yetenek Sinavlar Kılavuzu, Trabzon. 
Düzbastilar, M. (2020). The comparasion of music teacher candidates' instrument test grades and instrument sight reading grades in talent exam with individual instrument exam grades during four-years education period. Journal of Human Sciences, 17(1), 315-323. doi:10.14687/jhs.v17i1.5867

Güneştan, S. (2018). Resim-İs Eğitimi Anabilim Dah Öğrencilerinin Mezun Olduklarn Ortä̈ğretim Kurumlarna Göre Alan Derslerine Ait Akademik Başarlarmm Karşılaștrmlması, Doktora Tezi, Gazi Üniversitesi Eğitim Bilimleri Enstitüsü Güzel Sanatlar Eğitimi Anabilim Dalı, Ankara.

Keskin, H. Ü., Çiçek, E. U. (2005). Tanımlayıcı İstatistikler. Ş. Kalaycı (Ed.), Spss uygulamalı çok değişkenli istatistik teknikleri içinde, (s. 51-58). Ankara: Asil Yayın dağılım Ltd.

Köklü N., Büyüköztürk, Ş. (2000). Sosyal Bilimler İ̧̧in İstatistiğe Giriş, Ankara: Pegem A. Yayıncılık.

Köklü, N., vd. (2006). Sosyal bilimler için istatistik, Ankara: Pegem A Yayıncıllk.

Kurtuldu. M., K. (2014). Piyano Öğrencilerinin Deşifre Becerileri İle Piyano Dersi Başarılarının Karşılaştırılması, TS A / YIL: 18 S: 3, Aralık 2014. 